\title{
SOCIAL CUSTOMER RELATIONSHIP MANAGEMENT: A CASE STUDY
}

\author{
Konstantinos PALIOURAS and Kerstin V. SIAKAS \\ Alexander Technological Institute of Thessaloniki, Department of Informatics, \\ P.O. Box 141, GR-57400 Sindos, Greece
}

\begin{abstract}
Social Customer Relationships Management (CRM) is a current business trend providing new channels of two-way communication with customers through social media sites, such as Facebook, Twitter etc. Social CRM enables companies to interact in an easy and contemporary way directly with customers as well as to track customer interactions and their social influence. In this paper we examine the importance of CRM, e-CRM and Social CRM for businesses. We provide perspectives on objectives and types of CRM, the working cycle of CRM, the stages of a CRM Strategy and technology tools that are used in CRM. Social CRM is in particularly analyzed, since this new trend requires active engagement by customers and other stakeholders. The engagement process is essential to successful Social CRM and to successful social business practices. Finally, we describe experiences from three family businesses that introduced Social CRM as a result of a project carried out as an assignment in the 'Social Media Networking' module of the MSc course in 'Web Intelligence' at the Department of Informatics of Alexander Technological Educational Institute of Thessaloniki. The assignment of the groups was to create a Social CRM Strategy in collaboration with a company. This study is a follow-up of the outcome of the projects carried out in the autumn semester 2014 and 2015. The results show that all three companies consider that Social CRM is an excellent tool for obtaining real time valuable data about customers and a cheap way to reach them.
\end{abstract}

\section{JEL CLASSIFICATION}

$J E L M, J E L Z$

\section{KEYWORDS}

CRM, Social CRM, e-CRM, Social Networking, Social Media Marketing 


\section{INTRODUCTION}

Customer Relationship Management (CRM) is a process that companies use in order to improve business relationships with customers. Companies do this by using strategies and technologies to manage and analyse customer interactions, as well as data, throughout the customer lifecycle (Rouse, 2014). Their aims are to acquire, retain and increase customers. However, the main goal of CRM is to increase customer loyalty and in turn to improve business profitability.

\section{Objectives and Types of CRM}

CRM sets specific objectives, namely to include improvements regarding customer satisfaction and business sales enhancement. It can be divided into four basic types, based on characteristics. These are Strategic CRM, Operational CRM, Analytical CRM and Collaborative CRM (Tutorialpoint, 2014). Strategic CRM is a type of CRM, in which companies collect information about customers and market trends, in order to offer a better proposition to the customer. Operational CRM is focusing on the customer and includes business processes, such as services, marketing and sales. The following automations are included in Operational CRM: Sales Force Automation, Marketing Automation, and Service Automation Sales. Force Automation automates crucial sales of the company and the administrative functions of the sales force team. Marketing Automation automates marketing processes, such as customer segmentation and Customer Data Integration (CDI), which is the process of consolidating and managing customer information from all available sources (Rouse, 2005). Service Automation Sales diagnose and resolve issues related to products. Analytical CRM collects, stores and captures data from customers. It also includes the following applications: Sales Data (products, purchasing history), Financial Data (purchase history and credit score) and Marketing Data (customer response rates to marketing campaigns). Finally, in Collaborative CRM companies provide help to customers by sharing any information collected from interactions.

\section{CRM strategies and Technology Tools}

A successful CRM Strategy contains three fundamental areas: "who your customers are" meaning that it is necessary for a company to understand what kind of relationships it has to build with each customer, "How both parties obtain value from the relationship", pointing to a conclusion that both sides must obtain benefits or else a different strategy is needed, "Systems and software are only as effective as the strategy behind them", focusing on the importance of improving relationships through communications. As for the technology tools for Customer Retention, companies use tools such as Data Warehousing (DW), Data Mining, Database Queries and On Line Analytical Processing (OLAP). Data Warehouses are huge repositories of customer related data, accepted from various databases. Data Mining is a process of extracting patterns from large data sets, by using certain methods, in order to effectively collect these data sets for analysis and forecasting. By using Database Queries companies can access, modify and manage the databases through Structured Query Language (SQL) commands. OLAP is a known process of multidimensional analysis of elements which offers advanced abilities to the information analysis of a Data Warehouse.

\section{FROM CRM TO e-CRM AND SOCIAL CRM}

The first-generation applications of CRM appeared in 1980s in the form of Customer Information System (CIS). They were single function solutions designed to support a specific set of employees (Du, 2013). Nowadays with the evolution of technology a web-based CRM, called e-CRM, uses internet based technologies, such as forums, websites and emails to achieve CRM objectives (Technopedia, 2017). In other words, companies can interact with customers by using the internet. The main challenge of e-CRM is to offer successful communication and information regarding the topic of interest, in order to cover the particular needs of the customer. The internet provides a 
simple and ideal method, where customers can get answers they seek for, using sections for Frequently Asked Questions (FAQ), forums or chat rooms.

In addition to e-CRM there is also another new trend of CRM, called Social CRM. Social CRM is a customer relationship management process that provides communication through social media sites, such as Facebook and Twitter (Rouse, 2010). A business can create a particular page, usually called fan page, for the company in different social media sites, to quickly get information about users, who are interested in their products. In response to customer comments, a business can reply quickly to their questions, potential negative feedbacks, or product problems either by posting new comments, or by communicating with personal messages. By using Social CRM, companies can get higher reputation through offering the best possible solutions and suitable products to customers. According to a survey conducted by IBM in October 2010 (Davis, 2011), nearly 80\% of companies have a social media presence and most use social media for Customer Relationship Management purposes. The results of this survey shows us that Social CRM is a very important tool for business. In the following sections, we provide information about the usefulness and the challenges of CRM, eCRM and Social CRM.

\subsection{The Working Cycle of CRM}

Every CRM model contains a working cycle in companies that is oriented to the customer. The CRM model contains phases, which are followed by the business in order to achieve its goals. The following figure introduces the flow of the current model (Marketing Teacher, 2017).

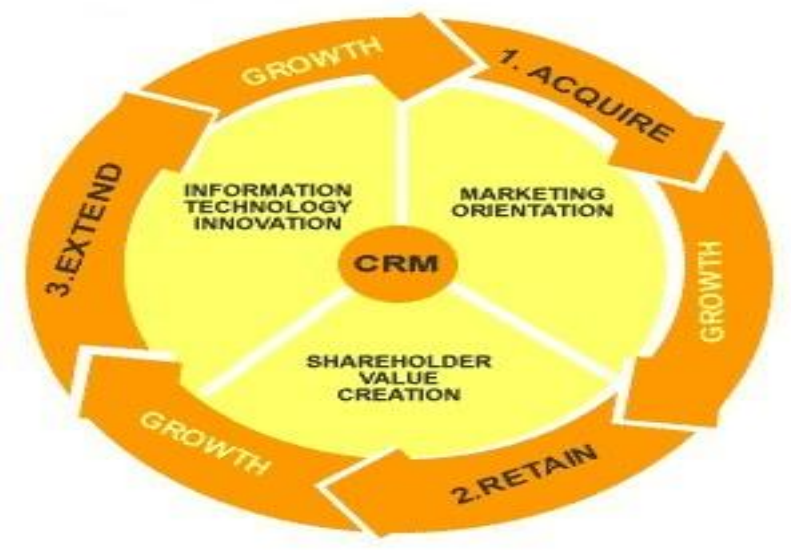

Figure 1: CRM model (Marketing Teacher, 2017).

1. Customer Acquisition - This is the process to attract a customer and convince him of making his first purchase.

Growth - Companies focus on increasing the number of their customers through market orientation, innovative Information Technology (IT), such as the use of physical devices to create, store, secure all forms of electronic data, and value creation.

2. Customer Retention - Customers return to the company and buy again. It is anticipated that they purchase a similar product or service.

Growth - Through market orientation, innovative IT and value creation, companies focus on increasing the number of their customers who will purchase from them regularly.

3. Customer Extension - Customers are regularly returning to purchase from the company. This time they have been informed about new products or services that may not be related to their original purchase. The main purpose on this stage is to retain them as customers for extended products or services. 
Growth - Through market orientation, innovative IT and value creation, the company focuses on increasing the number of their customers who purchase additional or supplementary products and services.

\subsection{The Stages of a CRM Strategy}

Preparing and implementing an adequate strategy for achieving desired result takes time. The following stages are used to build successful relationships with consumers (Sharp, 2003).

1. Interacting - In this stage, a dialog is been established between the customer and the organization. The discussion is referring to a series of interactions (eg. product in- information, product complaints) and transactions (eg. product order, service request).

2. Analyzing - Meaning that it is necessary to apply marketing practices (e.g. meeting the needs of customers, setting the accurate price) in order to create interactions that build valued relationships.

3. Learning - The purpose of this stage is about learning and to apply the information gained from analyzing customer behavior in order to create interactions between the customer and the organization.

4. Planning - The last stage is about planning the best possible market strategies and plans to meet the requirements of each customer, who is related with the particular organization.

The above steps are crucial for implementing a successful strategy, because today's consumers are much better informed, better educated and more demanding regarding the products and services that they require.

\section{TYPES OF CRM}

Customer Relationship Management software is being used by businesses, to guide them into an effective communication with their customers. Thus, the main purpose of a CRM application, is to help an organization understand the needs and behaviors of its customers and provide them better quality of service. There are four types of CRM applications: Strategic, Collaborative, Operational and Analytical to perform all these activities (Johnson, 2002).

Figure 2 shows the different CRM types and the relationship between them.

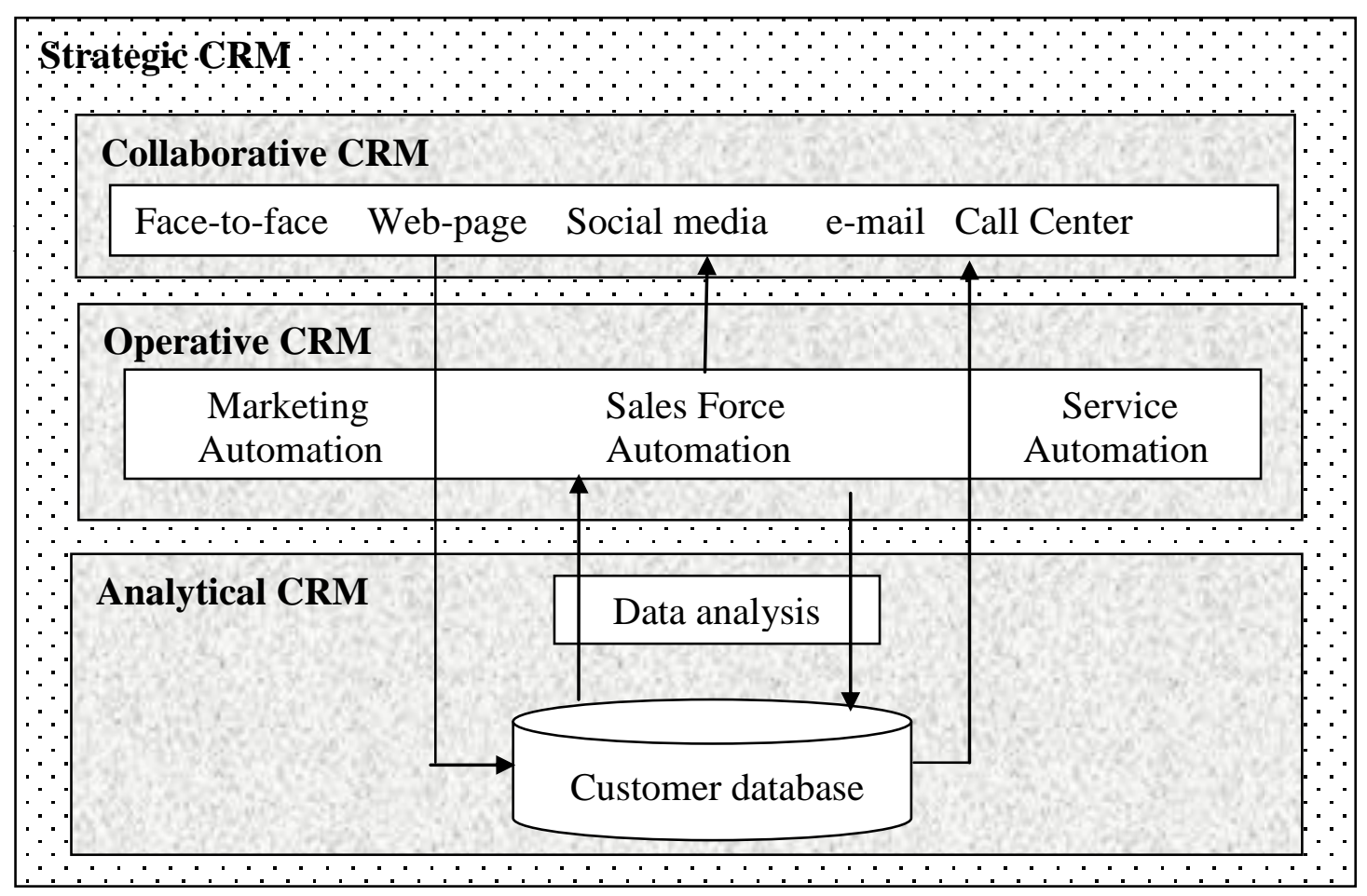


Figure 2: CRM types and their uses (adopted from Johnson, 2002)

Strategic CRM is focused on winning and retaining customers by creating and delivering better value propositions than competitors. The method is performed through capturing and collecting candidate data and market trends. As soon as the company completes the information analysis, it is able to adapt to customer requirements. The organizations will be in a better position to recognize the buying behavior of the customers and offer them better proposals.

Collaborative CRM is responsible for gathering data through various channels (fax, phone, web, e-mail) of communication of the enterprise with the customer. It can benefit the services of a company, because it manages the data in a way that facilitates interactions with customers. Collaborative CRM employs new communication systems, such as web forums, Voice over Internet Protocol (VoIP), and chat rooms. Thus, valuable information can be shared between companies and their business partners or customers.

Operational CRM refers to direct interaction between the customer and the company. Those interactions can be face-to-face, through websites, or calling centers. Operational CRM includes the following automations: Sales Force Automation, Marketing Automation and Service Automation. Sales Force Automation (SFA) was the original form of operational CRM.SFA is the application of technology to manage selling activities. It automates nearly a great amount of industry's sales and the administrative functions of sales force. For example, it is able to automate accounts management, contacts management, quote management sales management, monitor customer needs and their buying behaviors, as well as demographics. SFA tools are designed to improve sales productivity. Marketing Automation (MA) applies technology to marketing processes. It provides information about the external operational environment of an industry, including competitors and market trends. The intention of MA applications are meant to improve marketing's campaign profitability. This particular CRM software is well known as "front office" solution, due to its direct activity with the customer. Service Automation (SA) automates services requests, complaints, product returns and information requests. There are multiple communication channels (web, telephone, fax, face to face) to diagnose and solve product issues. SA is also capable of using Computer Telephony Integration (CTI), to provide advanced solutions.

Analytical CRM analyzes the information that was captured through Operational CRM in order to segment customers and enhance both customer and company value. The data is stored to repositories and categorized into sales (purchase history), financial (payment history, credit score), marketing (campaign response, loyalty scheme data) and service data. Analytical CRM helps companies to apply the best possible selling approach between customer groups. The interaction among high value customers, may be completed by "face to face" selling. As for the low value customers, they will probably be contacted by tele sales.

\subsection{The e-CRM process}

Many companies, due to internet's vital role on business life, apply eCRM, to reduce customerservice costs, tighten customer relationships and most important, further personalize marketing messages and enable mass customization (Namchul, 2005). The challenge of Ecrm is focused on specific information and communication about a product or a service that fits customer needs. It can be defined as an application which uses internet based technologies to achieve CRM objectives. The purpose is to retain customers and increase their loyalty to the organization. As we implement eCRM process, three steps in the life cycle is proposed (Buttle, 2010):

_. Data collection: Refers to the information regarding customer preferences. Data is collected via websites, social media, emails and questionnaires. 
2. Data aggregation: A technique that companies use to filter and analyze customer needs, in order to realize requests of customers.

3. Customer interaction: Companies provide specific feedbacks, to fulfil customer needs.

\section{DIFFERENCES BETWEEN e-CRM AND CRM}

An adequate method to succeed in Customer Relationships would be to integrate existing CRM processes with e-CRM applications (Pan and Lee, 2003). In order to apply this particular procedure, we need to understand the variances between CRM and eCRM. The traditional CRM model focuses on marketing sales, service support and customer interaction, through the integration of people and technology. As for the electronic version, it expands the techniques of CRM, through electronic channels, combining them with e-business applications for the implementation of the strategy. Figure 3 shows the main differences between e-CRM and CRM.

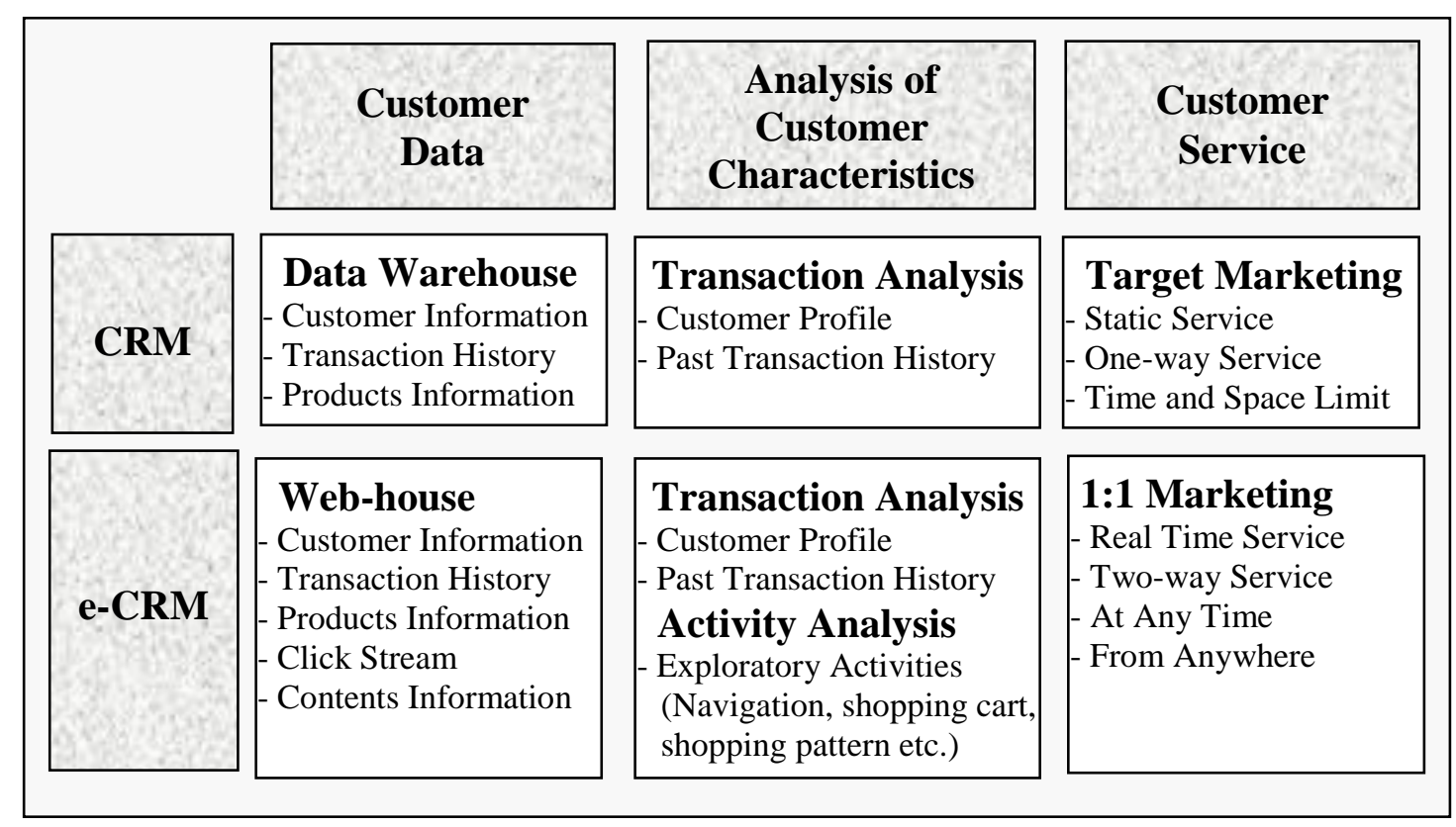

Figure 3: CMR in comparison to e-CRM

(adapted from Harrigan and Choudhury, 2010)

From figure 3 we conclude that CRM is offers many strategies into the area of business, but e-CRM offers possibilities to analyzing customer data and customer characteristics to a greater extent. Customer activities are captured through web-sites and social media. Another important difference is that e-CRM offers real time and two-way services at anytime from anywhere.

\section{SOCIAL CRM}

Social media, such as Facebook, Twitter, LinkedIn, YouTube, Google (+ and Analytics) etc. have become an integral part of modern society, and they have completely changed the way we communicate, share and co-create information. More and more businesses tend to use social media in order to advertise their brand and their products and also to achieve better communication with the consumers. (Siakas et al., 2014a). Social media has created new scope for CRM (Pan and Lee, 2003). Social CRM accounts for a new generation of enlightened customers. It is a business strategy supported by a technology platform and social characteristics, in order to provide beneficial value in a trusted business environment. Social Media Technologies are used to provide real time 
communications between customers and businesses (van Bruggen et al., 2010; Verhoef et al., 2010). This new approach of CRM uses social media to interact with customers. It requires strong relationships and conversations and is based on a customer engagement model depicted in figure 4. The main steps in the customer engagement model of Social CRM, include the following concepts: Customer Relationship Orientation, Relational Information Processes and Social CRM Technology Adoption. The concept of customer relationship orientation focuses on the implementation of a strategy for better understanding customer needs, through the development of close personal relationships, interactions and social exchanges (Chen and Ching, 2007). When a company gathers the required information Relational Information Processes takes place. Four dimensions of relational information processes have been reported by Harrigan and Choudhury (2012), namely information capture, information integration, information access, and information use. Information capture involves the gathering of information from users' posts in different social media, such as Facebook, LinkedIn, Twitter etc. Information integration requires the integration of customer information from all interactions to advance into a conclusion about each customer relationship. Information access to customer information is used by employees and strategic marketing decision makers (Chen and Ching, 2007). Finally the CRM Technology Adoption 'actually refers to the acceptance on part of the businesses for the collection, integration, and analysis of customer data, and subsequent communication with customers' (Jayachandran et al. 2005). This collection and analysis of the data is acquired by social media technology tools or web applications. Harrigan and Choudhury (2012) propose that the outcome from Social CRM implementation along with the customer engagement model and the technologies in social media leads to increased trust, brand loyalty, co-creation and empowerment.

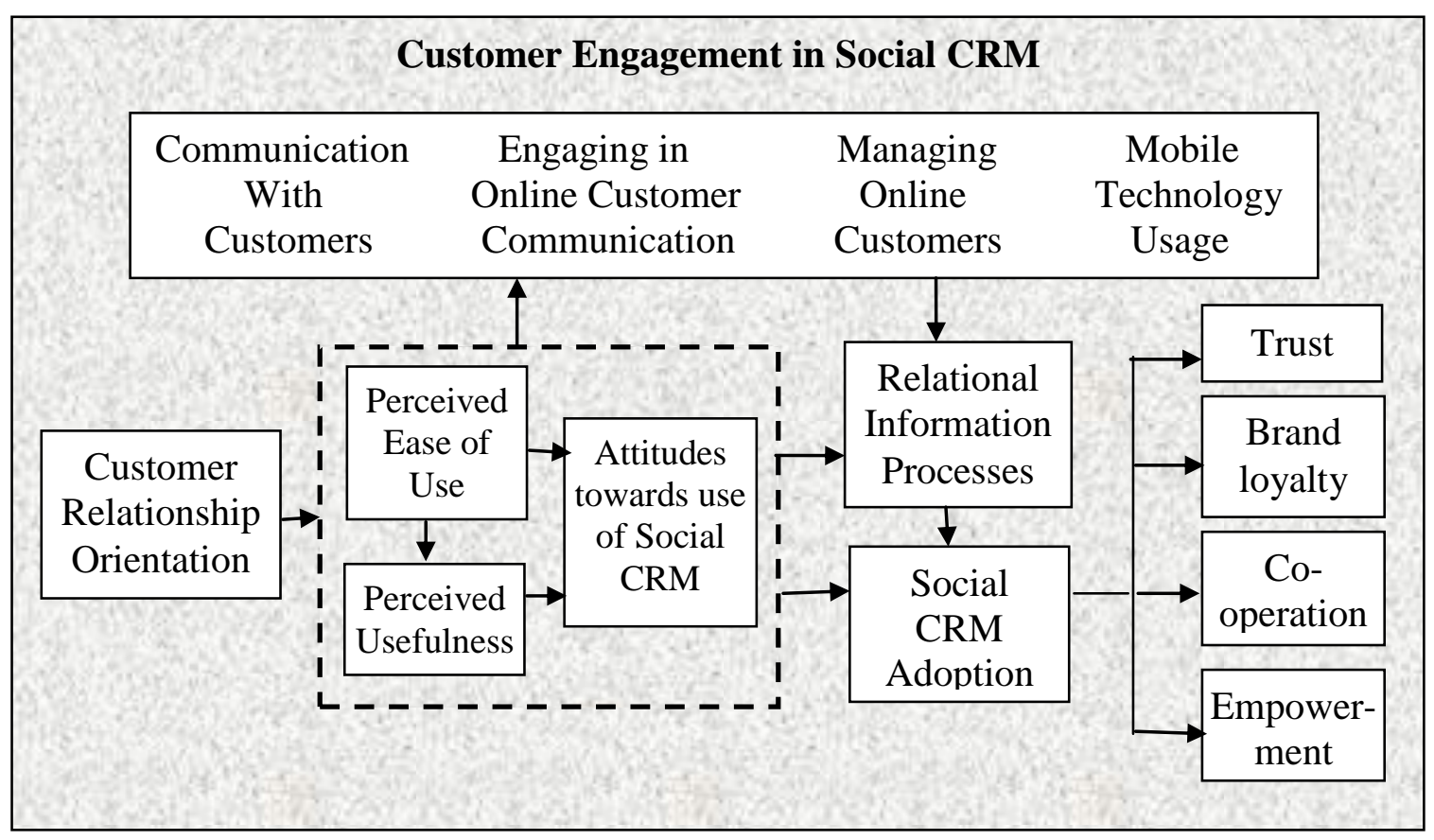

Figure 4: The Conceptual Model for Customer Engagement in Social CRM (adopted from Harrigan and Choudhury (2012))

Figure 4 proposes that customer engagement in Social CRM is achieved through customer relationships orientation, communication with customers and management of online customers through social media, mobile technologies and web-site usage. Customer Relationship Orientation includes dimensions such as perceived ease of use, perceived usefulness and attitudes towards use of Social CRM. In a study by Siakas et al. (2017) in students' perception of using social media in education it was found that other factors important for social media adoption were infrastructure for using social media, social influence and experience of using social media were important factors for 
social media adoption. It is likely that these factors also influence the readiness and attitude of customers towards Social CRM. The relational information processes include analysis of customer characteristics through customer transactions and activity analysis. The model suggests that the final outcome creates increased levels of trust, loyalty, co-creation and customer empowerment.

Companies aiming to use Social CRM need to be aware of the target group characteristics regarding degree of social media access. Figure 1 shows the S-curve, which is important for understanding when Social CRM is most efficient.

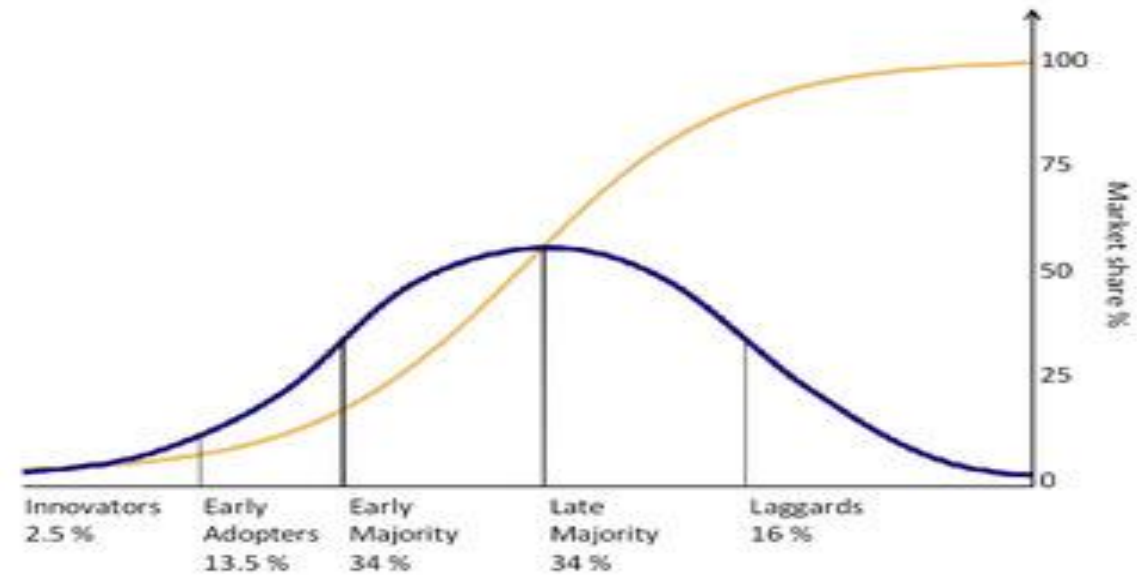

Figure 5. Take-up of New Technologies (Rogers, 1962; Fisher and Pry, 1971)

With successive groups of consumers adopting a new technology (shown in blue), its market share (yellow) will eventually reach the saturation level. In mathematics the $\mathrm{S}$ curve is known as the logistic function (Rogers, 1962; Fisher and Pry, 1971).

Social Media is characterized as the power of Word of Mouth accomplished through a bottom-up approach and crowd-sourcing (Siakas et al., 2014a; 2014b). Engagement in the Social Media means that customers or stakeholders become active participants rather than viewers. Participants engage in all forms of social discourse by acting together to equalize the market positions of manufacturers, suppliers, business and organizational leaders, customers and stakeholders in general. The engagement process is essential to successful Social CRM and to successful social business practices (Evans and McKee, 2010). The choice of suitable Social Media Networks, such as Facebook, Twitter, blogs, Wikis, newsletters etc., is important for obtaining expected results according to the marketing strategy. For example, targeted marketing is based on the characteristics of the target group we like to reach and the social media network should be chosen based on characteristics of the users of the Social Media (interests, age, gender etc.). Social Media Marketing is also called Word-of-mouth marketing or Viral Marketing, because it utilizes the nature of the social networks and the engagement of the participants. It spreads and diffuses the context in a new manner by involving the target groups unconsciously through competitions, comments (posts), ratings and interactions in general.

Regular users of social media, consider it a great place to find others working in the field, to share and build on information, rather than multiple users reinventing the wheel. With an increased focus on authenticity, trust and relationships are built through regular interaction, whether that is with new external contacts, or for internal communications. Users become adept at adapting to each new system. 


\section{THE CASE STUDY}

Three small Greek family businesses were accordingly introduced to a suitable Social CRM strategy created by three respective groups of MSc students. Each group consisted of 3-4 students enrolled in the 'Social Media Networking' module ${ }^{1}$ at the MSc Programme in 'Web Intelligence' at the Department of Informatics of Alexander Technological Educational Institute of Thessaloniki. The assignment of the groups was to create a Social CRM Strategy in collaboration with a company. The aims were also to help the companies implement the strategy suitable to the company aims and to create measures of the outcomes. The task included the following steps:

- $\quad$ Creation of a Social Media Vision: Determination of desired state.

- Formation of a Social Media Strategy: Identification of target group and differentiating activities.

- $\quad$ Establishment of Aims and Objectives: Identification of core competencies (differentiation from competitors).

- Determination of how to measure strategic success: Determination of Key Process Indicators (KPIs) and targets.

- Development of an Action Plan: Assignment of roles and responsibilities, content creation and process definition.

- $\quad$ Follow-up and continuous improvement.

In practice this meant that the InCISIV framework that had been developed under the auspices of the $\mathrm{VALO}^{2}$ project was implemented. The InCISIV framework facilitates the study of the relationships between Innovation, Communication and Valorization (actions of dissemination and exploitation) (Siakas and Georgiadou, 2012).

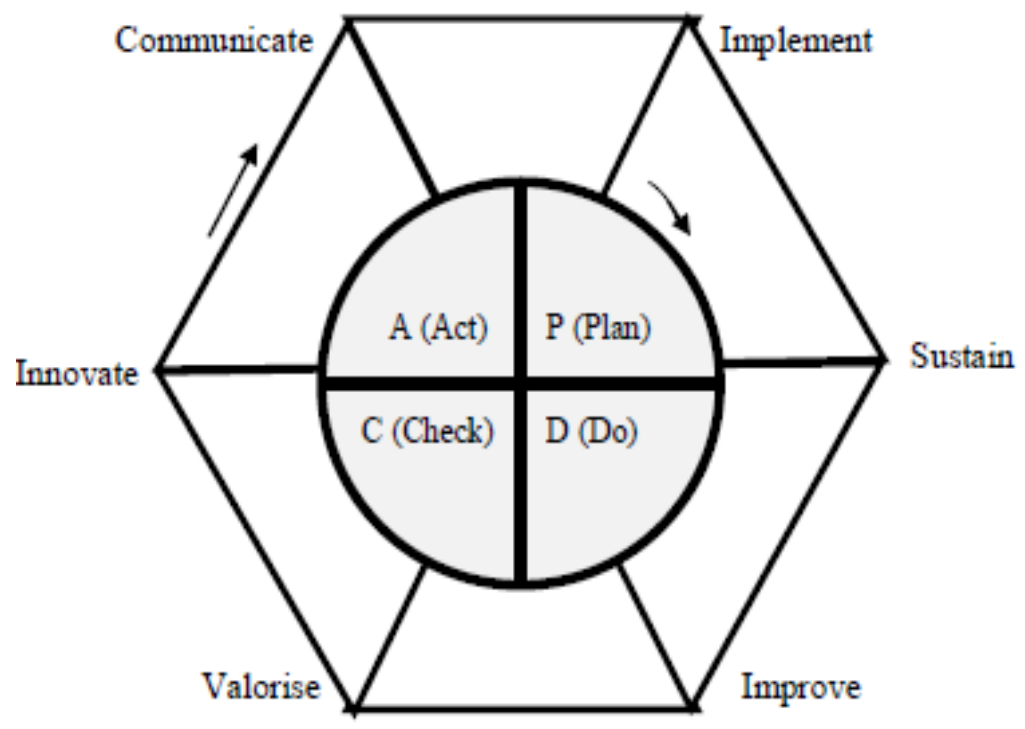

Figure 6: The InCISIV framework (Siakas and Georgiadou, 2012)

In the InCISIV framework the Deming Plan-Do-Check-Act Cycle, also called PDCA cycle (Deming, 1986) is embedded in the process quality model in an effort to focus project managers, project teams as well as evaluators to identify, plan, monitor, evaluate and improve their valorization of projects, activities and innovation. In our case study Social Media was used as a tool for valorization. The framework is depicted in figure 6 and shows two cycles which interact at every stage, delivering outputs incrementally. InCISIV allows for agile responses to change,

\footnotetext{
${ }^{1}$ http://www.it.teithe.gr/masters/mscsemesters

${ }^{2}$ www.valo.teithe.gr
} 
planning the quality strategy, continuous reviewing and evaluation of project progress and quality of deliverables as well as improvement suggestions.

At each stage activities are planned, carried out, outputs are evaluated and processes improved. The quality of outputs is thus continuously monitored, and sustainability is improved. As shown in the InCISIV framework every stage goes through the PDCA cycle and slowly the journey approaches its ultimate goal via different levels that have different characteristics (Siakas and Georgiadou, 2012).

The first step, the Innovation stage, comprised the new innovative way of communicating the core competencies to potential stakeholders (the target group) through the implementation of the social media strategy. Valorization is a continuous process that starts in the early stages of a lifecycle of a project and/or a product and is continuously improved according to the feedback from the target group/potential stakeholders for increased sustainability. The Social Media strategy and the embedded PDCA cycle helped to identify, plan, monitor, evaluate, improve and manage the valorization through Social Media activities and core competences.

Three family businesses implemented the InCISIV Framework through a Social CRM strategy with the help of the students.

\subsection{Company 1: A very small hotel in Northern Greece}

The family business hotel consists of 10 rooms with a fire-place and Jacuzzi in the rooms. The main customers until now were Greek clients who wanted to discover the hot springs or the ski centers in the surroundings of the hotel mainly during weekends. Most of the bookings were made through the Internet. Since the hotel owner is a young person he was open to new innovative ways of reaching the customers, in particular customers from abroad. Figure 7 shows the main areas of social media use in a hotel.

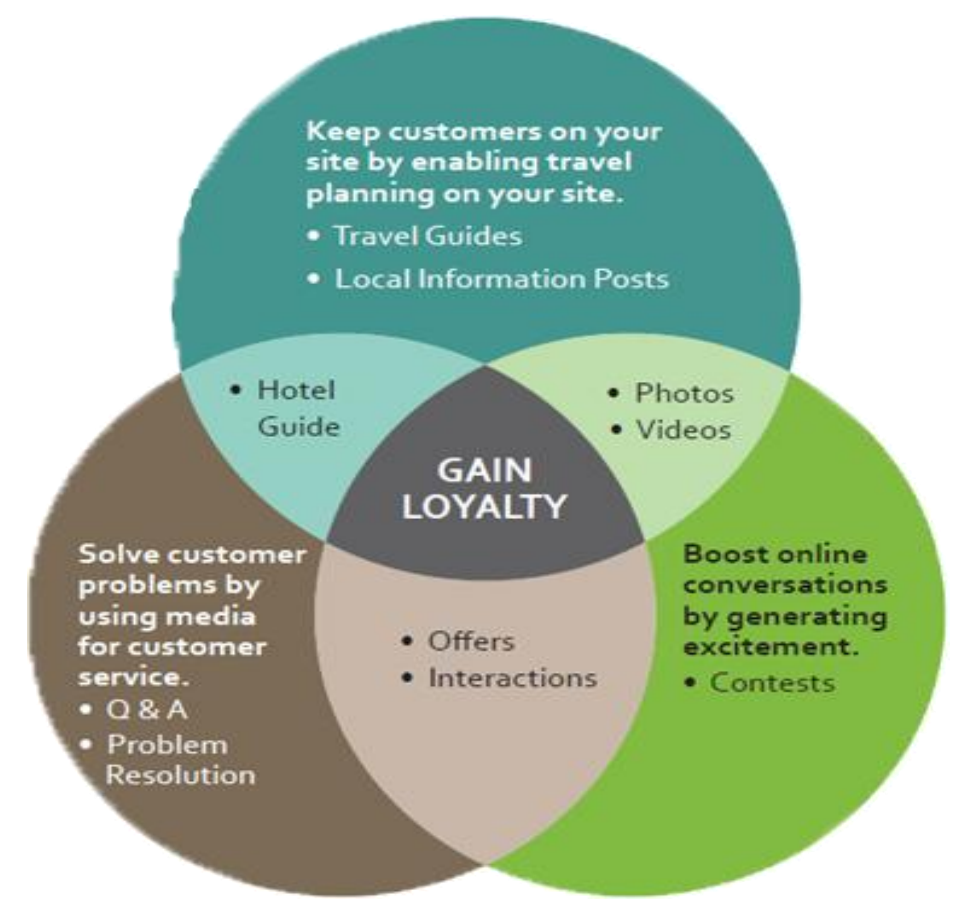

Figure 7: Uses for social media in a hotel (source: logannathan.com.au)

Gaining customer loyalty is an important hotel objective. Satisfied customers tend to come back and also tend to recommend the hotel to family and friends. The social media is an important mean for word-of-mouth marketing and customer participation (comments, photos and ratings). The main 
social media means that were implemented are: Facebook, Twitter, Foursquare and Youtube, as well as Trivago, Trip Advisor and Booking.

The first results of the implemented Social CRM were reported in Siakas et al. (2014b). The use of social media increased the bookings with 7-8\% in November 2014 compared to the previous year, despite the drawback of the financial crises. The branding was identified to have improved; the new customer base was identified to come mainly from abroad. The bookings were extended to week days and Sunday evenings. Customers comments were positive and customer ratings at Booking.com in March 2017 are 9,4/10. The owner is very satisfied with the results of the strategy developed through the Social CRM in collaboration with the students.

\subsection{Company 2: A very small 'cold-cuts and cheese' shop in Northern Greece}

The cold-cuts and cheese shop in Northern Greece demonstrated a significant improvement in brand name and customer comments and ratings after the implementation of the social media strategy (Siakas et al., 2014b). The students together with the owner carried out a SWOT analysis identifying the Strengths, Weaknesses, Opportunities and Threats. The Social Media Tools that were used are blog, Google+, Facebook, Twitter (multiple options of interaction), Google mapsplaces (interaction between customer and shop), as well as recipe competitions and campaigns through Facebook and Google AdWords. The results were very promising with a big number of visits in the blog, likes, posts and rating 4.8/5 (March 2017) in Facebook, as well as improved branding and increased sales. The owner is enthusiastic about the results. The Facebook is the far most popular social media used in particular by the younger generations, who ask for specific ingredients from the recipes. This movement has created a search for new innovative products and uses of existing products.

\subsection{Company 3: A small medical center in Northern Greece}

The third family business is a medical center for men and women, with innovative and specialized units in the fields of In Vitro Fertilization (IVF), maternal-fetal medicine, genetics and molecular biology. The center provides services and offers modern solutions to all kinds of infertility problems. The main concern is a humane approach providing psychological support to couples, combined with results, both in prevention and treatment. The center has around 20 members of staff.

The owner of the medical center asked for collaboration with the students one year after having seen a presentation of the student project from previous year. Two different groups of students worked with the company in 2015 and proposed two different Social Media Strategies. In end of 2016 the company employed a Digital Marketing manager, who would also be responsible for the presence of the company on Social Media.

\subsection{Responses of the three companies to the interview questions}

Table 1 shows the responses from the three companies to the interview questions.

Table 1: Responses to the interview questions by the three companies

\begin{tabular}{|l|l|l|l|}
\hline & Company-1 & Company-2 & Company-3 \\
\hline $\begin{array}{l}\text { Do you apply the social } \\
\text { media strategy } \\
\text { proposed? }\end{array}$ & $\begin{array}{l}\text { Yes, we to continue and } \\
\text { follow the strategy as } \\
\text { planned. }\end{array}$ & $\begin{array}{l}\text { Yes, we apply the social } \\
\text { media strategy proposed } \\
\text { three years ago by the } \\
\text { students }\end{array}$ & No \\
\hline & Yes, there is a person who & The owner manages himself & Digital Marketing manager \\
\hline
\end{tabular}




\begin{tabular}{|c|c|c|c|}
\hline & $\begin{array}{l}\text { monitors the customer posts } \\
\text { and responds to their } \\
\text { messages. }\end{array}$ & $\begin{array}{l}\text { the webpage and follows the } \\
\text { social media posts }\end{array}$ & started 3 months ago \\
\hline $\begin{array}{l}\text { Frequency of following } \\
\text { posts }\end{array}$ & Twice a week & At least five times daily & Daily \\
\hline $\begin{array}{l}\text { Employee opinions } \\
\text { regarding Social Media }\end{array}$ & $\begin{array}{l}\text { The employees and the } \\
\text { business operators believe } \\
\text { that social media have an } \\
\text { important role in promoting } \\
\text { the business. Because of this } \\
\text { we continue to frequently } \\
\text { update the profile of the } \\
\text { enterprise in the various } \\
\text { instruments. }\end{array}$ & $\begin{array}{l}\text { The store employees are } \\
\text { very positive regarding the } \\
\text { use of social networks and } \\
\text { actively participate in } \\
\text { creating own posts. }\end{array}$ & Necessary \\
\hline Customer opinions & $\begin{array}{l}\text { Customer feedback is mostly } \\
\text { positive. If there is negative } \\
\text { criticism, we take this into } \\
\text { account in order to improve } \\
\text { our business. If we make a } \\
\text { change in the business, we } \\
\text { inform it in our profiles on } \\
\text { the various social networks } \\
\text { so that our customers will } \\
\text { know. }\end{array}$ & $\begin{array}{l}\text { A positive acceptance by } \\
\text { customers, this savvy of } \\
\text { many likes and comments to } \\
\text { my posts. }\end{array}$ & Particularly positive \\
\hline $\begin{array}{l}\text { Have your customers } \\
\text { increased due to } \\
\text { presence of your } \\
\text { business at social } \\
\text { media? } \\
\text { What are the } \\
\text { advantages you can see } \\
\text { with using Social } \\
\text { CRM? }\end{array}$ & $\begin{array}{l}\text { Our main advantage is the } \\
\text { new clientele. Customers } \\
\text { who visit us usually report } \\
\text { their opinions about our } \\
\text { company through the social } \\
\text { networks they participate in } \\
\text { and so their friends become } \\
\text { our new customers. } \\
\text { Customers have increased } \\
\text { and in most cases they are } \\
\text { friends of friends. New } \\
\text { clients usually book though } \\
\text { the booking.com website. }\end{array}$ & $\begin{array}{l}\text { With the help of social } \\
\text { media we created a new } \\
\text { clientele mainly at younger } \\
\text { ages. Social media has the } \\
\text { advantage of image } \\
\text { presentation. I can upload } \\
\text { photos of my products in my } \\
\text { store and customers are } \\
\text { coming and asking to buy } \\
\text { the photos. }\end{array}$ & It is too early to say \\
\hline Customer ages & $\begin{array}{l}\text { The target group of the } \\
\text { company is } 18+\text { years. } \\
\text { Customers participating in } \\
\text { social networks are usually } \\
\text { from } 18-60 \text { years. }\end{array}$ & $\begin{array}{l}\text { Customers of all ages are } \\
\text { engaged in social media, but } \\
\text { most active ages are } 25-55 \\
\text { years old. }\end{array}$ & $20-55$ years old \\
\hline Challenges/difficulties & $\begin{array}{l}\text { There is a huge competition } \\
\text { in the region in the field. For } \\
\text { this reason, we strive to } \\
\text { become better and to show it } \\
\text { through Social Networks }\end{array}$ & $\begin{array}{l}\text { I must give daily attention to } \\
\text { the posts, but it is now easier } \\
\text { and more affordable thanks } \\
\text { to smartphones. }\end{array}$ & \\
\hline $\begin{array}{l}\text { Most popular social } \\
\text { media tool? }\end{array}$ & $\begin{array}{l}\text { Mainly Facebook and } \\
\text { Tripadvisor }\end{array}$ & $\begin{array}{l}\text { Certainly Facebook is the } \\
\text { most popular }\end{array}$ & Facebook and Youtube \\
\hline $\begin{array}{l}\text { How do you measure } \\
\text { success? }\end{array}$ & $\begin{array}{l}\text { From the opinion of } \\
\text { customers who come to our } \\
\text { hotel. Several times they } \\
\text { inform us that they have } \\
\text { learned about our hotel } \\
\text { through Facebook, booking, } \\
\text { Tripadvisor, etc. }\end{array}$ & $\begin{array}{l}\text { A long term goal is to } \\
\text { increase customers. Daily } \\
\text { we measure likes and } \\
\text { annotations on our posts }\end{array}$ & $\begin{array}{l}\text { Readability and increasing } \\
\text { incidents }\end{array}$ \\
\hline Future plans & $\begin{array}{l}\text { Soon it will refresh our } \\
\text { profile and also add } \\
\text { "Pinterest". }\end{array}$ & $\begin{array}{l}\text { We will continue our } \\
\text { presence on Facebook, but } \\
\text { we also plan to create } \\
\text { accounts on other social } \\
\text { media. }\end{array}$ & $\begin{array}{l}\text { It is something new for us, } \\
\text { we will expand depending } \\
\text { on the needs of each time } \\
\text { period }\end{array}$ \\
\hline
\end{tabular}


From table-1 we conclude that company-1 and company-2 implemented the social CRM proposed by the students in 2014. Both companies are very satisfied with the outcomes and also plan to extend their presence on social media in the future. Company-3 worked with the students on a social media strategy one year later (in 2015). The company has not applied the social media strategy proposed by the students, but instead recently employed a Digital Marketing manager, who is expected to actively promote the company through social media. The company already uses Facebook and YouTube in its social media marketing.

When asking the interviewed companies about what advice they would give to other companies the following advice was given 'A social networking strategy can only make good for an enterprise, provided the strategy is adjusted properly to the business and its needs. Social media is a contemporary word-of mouth tool that helps the company to be advertised and improved (when acting on negative comments) and this leads to increased profits'.

\section{CONCLUSIONS}

This paper examined the importance of CRM, e-CRM and Social CRM for businesses. In particular Social CRM, a new trend that requires active engagement by customers and other stakeholders, was analyzed.

We described experiences from three family businesses that introduced Social CRM as a result of a project carried out as an assignment in the 'Social Media Networking' module of the MSc course in 'Web Intelligence' at the Department of Informatics of Alexander Technological Educational Institute of Thessaloniki. The assignment of the groups was to create a Social CRM Strategy in collaboration with a company.

The results showed that all three companies consider that the advantages for a company of the appearance on social media are cost-related due to the free nature of their use and viral nature of social media that increased the customer base. The disadvantages were related to the time that was needed to monitor the traffic on the different social networks.

\section{ACKNOWLEDGEMENTS}

We want to thank the three family businesses for the collaboration with the student groups and for providing useful data of their companies.

\section{REFERENCES}

Buttle, F. (2009). Customer relationship management, 2nd ed. Amsterdam: Elsevier/ButterworthHeinemann, pp. 4-11.

Chen, J., Ching, R.K.H. (2007). The effects of Information and Communication Technology on Customer Relationship Management and customer lock-in, International Journal of Electronic Business, 5(5), pp. 478-498.

Davis, J. (2011). Social CRM: Winning the Battle of the Brands, http://evidencebasedmarketing.net/social-crm-winning-the-battle-of-the-brands

(Accessed 16th Febr. 2017).

Deming, W. E. (1986): Out of the Crisis: quality, productivity and competitive position, Massachusetts, USA. 
Du, W. (2013). CRM Basics, (Accessed16th Febr. 2017), http://www.tutorialreports.com/software/crm/basics.php.

Evans, D. McKee, J. (2010). Social Media Marketing: The Next Generation of Engagement. Wiley Publishing Inc. Indiana

Fisher, J. C., Pry, R. H. (1971), A Simple Substitution Model of Technological Change, Technological Forecasting \& Social Change, vol. 3 No. 1, pp.75-88.

Harrigan, P. and Choudhury, M. (2012). Technology Acceptance Model and The Social CRM: A Model for Customer Engagement, https://marketing.conferenceservices.net/resources/327/2958/pdf/AM2012_0091_paper.pdf.

(Accessed 16th Febr. 2017).

Jayachandran, S., Sharma, S., Kaufman, P. and Raman, P. (2005), 'The Role of Relational Information Processes and Technology Use in Customer Relationship Management', Journal of Marketing, Vol. 69, No. 4, pp. 177-192.

Johnson, L. K. (2002). New Views on Digital CRM, Sloan Management Review, fall.

Marketing Teacher (2017). Business Strategy and CRM, (Accessed 16th Febr. 2017), http://www.marketingteacher.com/business-strategy-and-crm/.

Namchul, S. (2005). Strategies for Generating E-Business Returns on Investment, pp. 354Rouse, M. (2005). What is customer data integration (CDI)? http://searchdatamanagement.techtarget.com/definition/customer-data-integration, (Accessed16th Febr. 2017).

Pan, S. and Lee, J. (2003).Using e-CRM for a unified view of the customer. Communications of the $A C M, 46(4)$, pp. 95-99.

Rouse, M. (2010). What is Social CRM? (Accessed 16th Febr. 2017). http://searchsalesforce.techtarget.com/definition/social-CRM.

Rogers, E. M. (1962), Diffusion of Innovations, the Free Press. New York

Rouse, M. (2014). What is customer relationship management (CRM)?, http://searchcrm.techtarget.com/definition/CRM, (Accessed 16th Febr. 2017).

Sharp, D. (2003). Customer relationship management systems handbook, 1st ed. Boca Raton: Auerbach Publications, pp. 9-11.

Siakas, K., Makkonen, P., Siakas, E., Georgiadou, E., Rahanu, H., (2017). Social Media Adoption in Higher Education: A case study involving IT/IS Students and Teaching Staff, International Journal of Social Media and Interactive Learning Environments, (see http://www.inderscience.com/jhome.php?jcode=ijsmile)

Siakas, K., Kermizidis R., Kontos K. (2014a). Using Social Media in Business as a Tool for Open Innovations, Business-Related Scientific Research Conference (ABSRC 2014), Milan, Italy, Dec. 10-12.

Siakas K. V., Belidis A., Siakas E. (2014b). Social media marketing for improved branding and valorisation in small family businesses, International Conference on Contemporary Marketing Issues (ICCMI 2014), 18-20 June, ISBN: 978-960-287-145-4, Athens, Greece, pp. 764 - 772.

Siakas, K., Georgiadou, E. (2012). Quality Process Model: Towards Maximising the Quality of Social Impact through Valorisation, in Proceeding of INSPIRE 2012, August, Tampere, Finland, The British Computer Society, pp. 89-100.

Technopedia (2017). Electronic Customer Relationship Management (E-CRM),

https://www.techopedia.com/definition/30914/electronic-customer-relationship-management-e-crm, (Accessed 16th Febr. 2017).

Tutorialpoint (2014). CRM - Types, (Accessed16th Febr. 2017).

https://www.tutorialspoint.com/customer_relationship_management/.

van Bruggen, G. H., Antia, K.D., Jap, S.D., Reinartz, W.J., and Pallas, F. (2010).

Managing Marketing Channel Multiplicity. Journal of Service Research. 13(3), pp. 331-340.

Verhoef, P.C., Reinartz, W.J., and Krafft, M. (2010). Customer Engagement as a New Perspective in Customer Management, Journal of Service Research, 13(3), pp. 247-252. 
Vlachakis S., Siakas K.V., Naaranoja, M. (2015). Internet and Social media: the Main Marketing tools for Small Family Businesses, International Conference on Contemporary Marketing Issues (ICCMI 2015), 30 June - 3 July, Kingston University, London, UK. 